\section{Original} Article

\begin{tabular}{|l|}
\hline Access this article online \\
\hline $\begin{array}{l}\text { Website: } \\
\text { www.ajobe.org }\end{array}$ \\
\hline DOI: \\
10.4103/1817-7417.86042 \\
\hline Quick Response Code: \\
\hline
\end{tabular}

Address for Correspondence: Msgr Prof Dr Obiora Ike, Catholic Institute for Development, Justice and Peace (CIDJAP) 3 Ikwuato Street, Uwani, P.O.Box 302, Enugu, Nigeria. Email: obiorike@yahoo.com

\title{
Business Ethics as a field of teaching, training and research in West Africa
}

Obiora lke

Department of Business \& Social Ethics, Catholic Institute for Development, Justice and Peace (CIDJAP), Enugu, Nigeria

\section{ABSTRACT}

Business Ethics as a field of teaching, training and research has appeared on the scene, as a panacea after several negative incidents of unethical global business practices, to offer sound principles and elucidate on the fact that the increase in corporate and individual corruption leads to a general decay of society. It is indeed in the interest of all to have a balanced society founded on business practices which are alongside other factors, ethical and therefore sustainable. This article is a modest attempt to provide the results of a survey conducted in the sub-Saharan region of West Africa, elucidating on attempts to gain a better understanding of the prevalence and scope of teaching, training, and research in the field of Business Ethics. The conclusion shows gaps in the study of Business Ethics within the region, but also portrays the available existence, practice and prevalence of Business Ethics within traditional African culture in West Africa.

Key words: Business Ethics, Teaching, Training, Research, West Africa

\section{INTRODUCTION}

This article reports the results of a survey conducted in the sub-Saharan region of West Africa, elucidating on attempts to gain a better understanding of the prevalence and scope of teaching, training, and research in the field of Business Ethics. It starts off with a brief overview of the West Africa region, after which methodological considerations relevant to the survey in this region as well as the findings of the survey in this region are discussed. In the conclusion of the article it is shown that gaps do exist in the study of Business Ethics within the region, but that the survey has uncovered the existence, practice and prevalence of Business Ethics within traditional African culture in West Africa.

\section{OVERVIEW OF THE WEST AFRICA SUB-REGION}

There are 18 countries in West Africa all of which belong to the Economic Community of West Africa (ECOWAS). For practical purposes however, the author was allocated only some 14 countries within the sub region-for study. These are Benin, Cameroon, Chad, Equatorial
Guinea, Gambia, Ghana, Guinea, Liberia, Mali, Niger, Nigeria, Sierra Leone and Togo. Other countries within the sub region such as Senegal, Ivory Coast, Mauritania and Burkina Faso were assigned for research under the Central \& Francophone African region. Within West Africa, Nigeria is the largest country with a population of over 180 million people. The other countries mentioned provide another 120 million people, making the West Africa region an important and demographically large zone within Africa, with enormous economic, political and natural resources. Nigeria alone has 450 tribes and over 500 independent languages spoken, within one country. The other countries mentioned together provide another 500 languages.

There are major ethnic nationalities and groups who live and thrive beyond state boundaries such as the Hausa, Fulani, Igbo, and Yoruba to mention but a few. Four major European languages are spoken in the zone following Africa's colonial history of the $19^{\text {th }}$ and $20^{\text {th }}$ centuries, namely: English French, Spanish and Portuguese. In the midst of plenty, and in spite of the enormous potentials in human, natural and mineral resources in the 
West Africa zone, exploitation, bad business practices, lack of good governance and other historical and structural factors have made poverty a reality in the zone. This type of poverty is both scandalous and unacceptable because the major industrial players in the global oil, gas and mineral resources industry rake billions of dollars in profit monthly from the countries of West Africa and with a better business model, life could be better and sustainable for both communities and businesses. Getting the systems working is possible under a motto of sustainable economic development led by socially responsible businesses and individuals in both the public and private sectors.

\section{EXISTING LITERATURE ON BUSINESS ETHICS AS A FIELD OF TEACHING, TRAINING AND RESEARCH}

Although a substantial number of publications dealing with the theme of Business Ethics were identified in the West Africa region (cf. Edozien, 2007; Elegido, 1996; Ike, 2001, 2003 and 2004) no literature could be found that reflects on the status of teaching training and research in the field of Business Ethics.

\section{REGION-SPECIFIC METHODOLOGICAL CONSIDER- ATIONS}

The research methodologies utilized in this survey include a desktop survey of publicly accessible information on websites, a literature survey, survey questionnaires for individuals and institutions, and personal contacts achieved through meetings, travels, phone calls and email exchanges with individuals who are either practitioners in the field of Business Ethics or who have information relevant to the subject of research. Data were also collected from online databases. Individuals of interest on issues related to Business Ethics, but of limited literary capabilities were also resourceful in their contributions to the subject of research.

The research identified individuals who put in a reasonable amount of their time in discussing issues concerning Business Ethics, or in the publication of articles in Business Ethics journals or at institutions, which offer elective or mandatory modules or courses on Business Ethics. About 50 volunteers collaborated within the sub-region with the research through networking of individuals at different points. They offered invaluable help towards this research project. It is worthy of note to state that the contributions of these individuals were oral. These oral traditions could impose limitations due to illiteracy of the western languages of interview such as French and English writing and communication. But their contributions are very helpful since they give an experiential account based on knowledge and involvement at the local level of the market activities where the concepts and issues in Business Ethics are practically expressed.

\section{FINDINGS}

The findings of this research show the existence and prevalence of Business Ethics ideas in traditional and culturally rooted African thought patterns. These are embedded in the local philosophies and wisdoms of the people and in the cultures and cultural patterns of the indigenous tribes of West Africa. Education may be acquired through schools in modern societies, but many African peoples, who did not and do not attend these koranic or western-style classroom education systems, acquired knowledge and character through traditional models and educational methods. Such traditional value education was founded on lifestyles that were respectful of creation and environment, of the elders, and of traditional institutions and the norms of society. Oral interviews revealed that many of the language groups, tribes and ethnic nationalities in the West Africa sub-region have a concept of the market, monetary transactions, agreements, justice, truth, integrity and Business Ethics around which local proverbs and religious moral norms were built. For a person to be respected within the community, one must be respectful of the traditions left behind by the ancestors, conveyed through culture, language, art, dance and religious symbols and values. Therefore, persons in the local communities were expected to live a life of integrity and respect within the family, the clan, the village and the larger society. To behave contrary was a disgrace to the community and was often met with stiff punishment.

Irrespective of what has been said of the existence of morality and general Business Ethical ideas in traditional society, there is of course, the scientific discipline around the subject which is carried out at the universities and educational centers of higher learning, including specialized institutions which offer Business Ethics as a tool for learning, teaching and research. Our findings reveal the existence of the following number of universities in the West African sub-region: Nigeria: 147; Ghana: 13; Guinea Bissau: 4; Liberia: 9; Mali: 9; Chad: 2; Benin Republic: 4; Sierra Leone: 2; Gambia: 1; Niger Republic: 2; Cameroon: 13; Equatorial Guinea: 2; and Togo: 2. Most of these universities do not offer specialized courses on the topic of Business Ethics as an independent field of study. Observations however show that these institutions generally offer courses in General Studies at the university level for all students on the topics of philosophy, religion and ethics but not necessarily on the theme of Business Ethics as a particular field of study, research and training. The institutions that are involved in Business Ethics as a field of teaching, training or research are often private universities, Christian specialized institutions and seminary institutes. Hardly does any state funded public institution offer Business Ethics as course of study with deepened reflection and academic proficiency in the West Africa sub-region. 
In the following sections the following aspects of our findings will be reported: Terminology and conceptualization of Business Ethics, prevalence and distribution of Business Ethics in the region, focus areas in Business Ethics, themes in teaching in Business Ethics, themes in training in Business Ethics, themes in research in Business Ethics and the major business ethical issues foreseen over the next five years in the region.

\section{Terminology and conceptualization of Business Ethics}

It has already been mentioned that the conceptualization of Business Ethics as a specialized field of teaching, training and research in universities and institutions in the West African sub-region is novel and limited. Likewise, there are only a handful of lecturers who actively engage with the subject of Business Ethics in this sub-region.

The idea of ethics in business in this sub-region is factually existent, as it is found in the thought patterns, language, practices and moral beliefs of the people. People talk of ethics, Business Ethics and financial ethically behaviors in their everyday lives with respect to ought-ness, duty and responsibility. Stealing and cutting corners are censured and considered morally reprehensible. The idea of justification of acts, the rightness or wrongness of issues, work, transactions, contracts, buying and selling are well pronounced in the daily affairs of the people. This could be seen from the angle that most of the West African countries are traditionally inclined to the concept of what is good as to be done and what is evil as to be avoided. Issues are in most cases attributed to some spiritual or supernatural forces, which in turn influence their day to day activities. And as such, ethics, including Business Ethics, comes into play in all that people do.

There is evidence from the survey that the concept 'Business Ethics' is minimally used in some countries in the sub-region, while a good number of tongues and languages in the subregion refer to other terms that are related to Business Ethics. Prominent in this regard are concepts like ezi onu ahia (good market price), ahia oma na ere onwe ya (good market sells itself), egbe bere ugo bere (win-win scenario is best strategy; let the kite perch and let the eagle perch too); I bu nkem, abum nke gi (inclusion, not exclusion; you are mine and I am yours) Nwa ka ego (a child is more valuable than money); Afam efuna (my name is worth more than wealth); Nwa m kwuba aka gi oto (my child be fair, ethical and just). There are other concepts in the Northern Hausa speaking areas of West Africa including Chad, Niger, northern Cameroon, northern Ghana and Burkina Faso which say: kasua mai chau (a good business; a good market). It is observed that Business Ethics as a term is still growing in its specific understandings in the region. This could be attributed to the gradual growth and introduction of the concepts of Business Ethics in the scientific study of higher learning. Thus, the issue of conceptualization of Business Ethics in this sub-region has a great potential in view of the influx of ideas from all parts of the world, which confront traditional and indigenous knowledge for which the transfer of knowledge and exchange across cultures is important. It is this formulation of ideas or birth-giving to fresh thoughts that should help improve or advance Business Ethics in the West African sub-region. The situation can thus be summarized as follows:

- Business Ethics is developing within the sub-region as a specialization.

- There is a limited number of teachers offering courses or doing research in the field.

- The institutions that teach Business Ethics are also limited in number, and as such, rather than studying Business Ethics specifically, they engage in the wider spectrum of ethics studies including economic ethics, social ethics, media ethics, and other forms of ethical studies. Such teaching is normally offered by the disciplines of Philosophy and Theology.

\section{Prevalence and distribution of Business Ethics in West Africa}

From the findings of this research it is clear that Business Ethics is neither prevalent in the sub-region of West Africa, nor is it eloquently pronounced. It is also not as widely spread as one may expect, knowing fully well that in traditional culture and thought patterns, the values and issues of Business Ethics had generally been acknowledged. In modern society however, the sampled opinion of some of our contacts is that they hear more of issues of Business Ethics at the levels of discussions on Enron, Shell, Chevron, banks, big business and multinational corporations. Business Ethics does not seem to convey the idea of simple honest behaviors that teach virtue and character. Students confront the concept only in the classrooms and at higher university levels. Since state owned and public universities do not offer courses on Business Ethics as a specialization, students who were interviewed claimed ignorance of its existence. The prevalence and distribution in West Africa is thus low. The cities where big corporations exist have a better chance to develop content around the topic of Business Ethics unlike locations where big businesses do not exist.

Students often do not have the opportunity to study Business Ethics in universities because it is not offered and it is not generally public knowledge. Many stated that if it was offered and known, they would be glad to study the subject as it resonates with their concepts of morality and religious values. Research also showed that few teachers share their knowledge on this subject matter with their students, because the teachers themselves are neither specialized nor tutored. Let it be said that Business Ethics is generally found in persons seeking post graduate studies who already possess their first degrees and seek to obtain a second or higher degree such as the masters. Often, it is difficult to find students desiring to carry out research 
at the first degree level in the subject of Business Ethics. Candidates for Business Ethics in many of the countries under study are rather persons who are graduates. This study shows the prevalence, distribution and participation of individual teachers and institutions in Business Ethics as a course of study within the sub-region, as listed below:

- Benin Republic: There are four universities in the country. But none of these universities offer courses on Business Ethics as an elective subject. Such course is only offered by the Institute of Justice, Development and Peace run under Father Raymond Goudjo, German trained Director of the Institute. The centre conducts theoretical and practical courses in Business Ethics.

- In Cameroon, which has 9 Universities, only the Catholic University of Central Africa located in Yaoundé teaches and offers Business Ethics in its curriculum as a subject for research and teaching. And this is happening in a country which is described and rated by Transparency International on their Index as the most corrupt country in the world. In Cameroon, public universities do not offer Business Ethics as a field of study. The undergraduates only take some elective courses in the areas of philosophy, management and social sciences and administrative courses.

- Chad, one of the poorest countries in the Sahel regions of Africa with a predominantly Muslim population has been embroiled in intermittent wars within and without for the past 20 years, making it virtually impossible for development to take place. Even though it established a University in 1971, located in N'Diamena the capital of the Saharan country with affiliations to the National School of Administration and the National Institute, there is a complete absence of the topic and subject of Business Ethics at any level. Mandatory Courses in social studies and administration are offered as part of the curriculum of studies.

- Equatorial Guinea, a Spanish speaking country has 2 universities with no Business Ethics as a field of study or research, teaching or training in any of them. During the course of this research, I visited this small island country, richly endowed, but ruled by a maximum dictator for life who is virtually in charge of everything, businesses, lives and resources. With a very small size and population, Malabo its headquarters, is a developing tourist centre, richly endowed with oil wealth spread unevenly. There is thus a need for the inculcation of Business Ethics in its culture and society, both for the foreign multinationals drilling oil in that country, and for the citizens, especially the youth.

- The Gambia, located on the shores of the Atlantic on the south and bounded by Senegal on the other three sides is a highly populated Muslim country on the West Coast, a tourist destination in West Africa. The subject of Business Ethics is not taught in any institution. During my visit to this country during the conduct of this research, I was able to visit the only university in the country, located in Kanifing, south of Banjul and operating since 1996 and started with funding from the Islamic Development Bank. Business Ethics as a course of teaching does not exist on the curriculum of studies of this university. There are large numbers of promising young lads who would benefit from school education, but poverty and lack of access remains a great handicap in this nearly water and land locked country. There are not sufficient teachers to offer the basic subjects of Business Ethics and many students do not have knowledge that such a subject exists. The university is still young and is facing infrastructural challenges. Nationals of other countries take over this responsibility.

- Ghana is a culturally rooted country with great potentials of human, material and natural resources within the sub-region of West Africa. A country with a population of over 20 million persons, 6 public universities, 7 professional institutions; one regional university and 9 private universities, Ghana has all it takes to be prolific and efficient in the discipline of Business Ethics as a field of study and research. On the topic of Business Ethics, in Ghana some universities and higher learning institutions offer courses on Business Ethics such as the elective and compulsory courses at the University of Ghana, Legon where the GIMPA /Ghana institute of Management and Public Administration) is also situated. The Catholic University College of Ghana offers courses on Catholic Social Thought and Business Ethics as part of its philosophy and religious courses. Other universities which carry out specific studies in the area under discussion are the Kwame Nkrumah University of Science and Technology, University of Cape Coast, Cape Coast University of Education, and the Winneba University for Development Studies. The Christian Service University College of Ghana, Fiapre, Sunyani and some other Christian oriented private university faculties offer basic studies on the subject of ethics and religion.

- Guinea with just one university recently opened in 2007 is still grappling with infrastructural development, governance issues and need for professionals to manage its curriculum and programs at Conakry, the capital city. The subject of Business Ethics is not available on its timetable yet.

- Guinea Bissau, which speaks Portuguese, the language of its former colonial ruler, namely Portugal has four universities. The Amilcar Cabral University - since 2008 suspended for three years in that country; The University of Colinas de Boe; The University Lusofona, an extension of the Portuguese university bearing the same name; and the Jean Plaget University. The subject of Business Ethics as a field of study, teaching and research is virtually absent. 
- Liberia has one of the oldest universities of Africa, founded in 1862 as the Liberia College under the United States of America and later becoming a fully independent university in 1951. The University of Liberia is a publicly funded institution of higher learning located in Monrovia, Liberia. With five colleges, three professional schools and three graduate programs, the College of Business and Public Administration offers general courses on ethics, religion and business studies. Liberia has just emerged from a destructive and damaging war, whose effects still linger to this day. There are no specific offerings on Business Ethics as a subject for teaching, research or training.

- Mali, a majorly Muslim populated country has the world's first and oldest university located at Timbuktu and founded in the $11^{\text {th }}$ century during the height of the reign of the great Alhaji Mansa Kankan Musa of the famous historical Mali Empire. It was founded as an Islamic centre of learning and has remained so till date. In the present times, another university has been constructed at Bamako, the country's capital city. The Islamic university trains students in various professions and graduates them for the challenge of today. It did not show from our studies that the subject of Business Ethics is offered to the students, nor do the teachers have the training, research and expertise in the subject.

- Niger Republic has one university known as the Islamic University of the Niger which has no course on the subject of Business Ethics. The country is hard hit by the Sahel region's bad weather and the Sahara desert has engulfed it completely. Much effort is spent, trying to develop the county despite natural disasters and difficulties. The subject of Business Ethics is absent, even though, there is a study of Islamic culture and religion connotations, of the Koran, and of the Surah and the Hadith of the Prophet.

- Nigeria is the largest and richest country in West Africa and the most populated black nation on earth. With a population estimated at over 180 million people, Nigeria has about 147 Universities, and only recently in 2011, another 9 Federal Universities were licensed by the Federal Government. There are over 40 private universities in the country; many of them owned by Christian denominations, church groups, and individual and private interests of different persuasions. The private universities offer courses on the subject and discipline of Business Ethics with curriculum, content, research themes, training and teaching staff. The Pan-African University in Lagos was the first privately licensed university in Nigeria with linkage to the Catholic Church. It has the best organizational and capacity structures for research, training and teaching on Business Ethics. The Lagos Business School does training for personnel of banks, firms, organizations, government top staff, management cadres and the civil and political leadership of the country. The Catholic Institute for Development, Justice, Peace and Caritas (CIDJAP) founded in 1986 in Enugu sets itself to address the need for filling the gap in society by training middle and top persons in the areas of Social Ethics, Business Ethics, Political Ethics, Economic Ethics, Cultural Ethics and other areas of professional Ethics. Furthermore, the Catholic Institute carries its training beyond its doors to institutions, persons and groups outside through animation, training workshops, weekend seminars and engagement of civil society to focus on issues of the environment, ecology and climate change, the international debt question, the trade in arms and narcotics, prostitution and child trafficking to mention but a few. CIDJAP works through theory and practice and partners with affiliate institutions such as the newly established Godfrey Okoye University, a private Catholic institution of the Diocese of Enugu. There has been some form of Islamic ethics and Business Ethics at the Bayero University in Kano, northern Nigeria. The Growing Businesses Foundation in Lagos (2000) initiated by one of Nigeria's leading female voices, Ndidi Nnoli-Edozien engages in dialogue with conglomerates doing businesses in Nigeria, challenging them on the issues of corporate governance, sustainability and corporate social responsibility. The University of Nigeria, Nsukka, and other private and a few public universities, the Enugu University of Science and Technology which has a business school, and the University of Ibadan make a strong contribution to the topic of Business Ethics as a field of learning, training and research in Nigeria.

- Sierra Leone has two universities namely, the former Fourah Bay College which is today the University of Sierra Leone and the Njala University, established as a public institution by the Universities Act of 2005. After the war which ravaged the country, effects of the war has made it practically impossible for any meaningful engagement with studies on Business Ethics, although the country is involved in the large scale production and mining of mineral resources such as gold and diamonds, which make it a haven for criminals, smugglers and multinational firms who often do not pay tax and engage in unethical conduct.

- Togo, a small country in West Africa has continued quietly to gain from its British and German colonial history through sustaining an environment of peace to ensure progress and development. There are two universities, namely the University of Lome and the newly created Catholic University of Togo, an affiliate of the larger Catholic University of West Africa, owned and managed by all the catholic bishops of the francophone countries in West Africa. The subject of Business Ethics is not fully developed, but is approached from the point of view of ethics and management of society. 


\section{FOCUS AREAS IN BUSINESS ETHICS}

Business Ethics in the West Africa sub-region focuses on a variety of issues related to the meaning and ethical justification of the day to day business encounters or transactions in which people engage. There are some areas that have been identified as the areas of concern by people that do Business Ethics in the sub-region of West Africa. These areas include:

- Social responsibility in the management of business;

- Corporate governance;

- Corporate compliance and ethics;

- Public sector governance;

- Ethics and employees;

- Corporate social responsibility;

- Work ethics; and

- Traditional legal reasoning and business rationality.

In these areas, the scholars of Business Ethics reflect on issues related to the justification of business, and the moral rightness or wrongness of some business transactions which have the potential of being harmful to the human person.

\section{Themes in training on Business Ethics}

The themes that have been developed in training on Business Ethics in the West Africa sub-region focus on exploring the role of Businesses in the development of a nation. Sustainable economic development must be led by socially responsible businesses and persons. Only through this means can good governance and democratic ideals have an impact on the concrete lives of people. Business education in public and private universities and institutions is critical and the position of the faith-based organizations is to consider Business as a calling.

Themes for training in Business Ethics include issues of sustainability; subsidiarity and solidarity issues; the role and protection of the African family in business; the protection of women and youth from exploitation; the prevention of war and the promotion of peace and dialogue; corporate governance; the role of labour in promoting a dignified human existence; community and businesses relations (as in the Niger Delta regions and in the mineral and oil producing countries); between nature and nurture; and between governments and their people so that business concerns do not harm or exploit people.

\section{Themes in Business Ethics research}

The major themes in Business Ethics research are:

- Corporate governance, which involves the proper role and model of distinguishing competencies and driving an organization without conflict of interest and under clear division of labour;

- Employment issues and the management of employer and employee conflict;

- Traditional social-market economy in a global environment, whereby inclusive and not exclusive economic practices hold sway;

- Granting access to the voiceless and the poor so that this world would be governed by win-win scenarios and the poor retain their dignity;

- Family values in the world of business;

- The care for creation and environmental protection; and

- The youth and growing issues of unemployment.

Major Business Ethical issues over the next 5 years

There are key issues which shall engage Business Ethics in the next five years in West Africa, some of which shall be the urgent matters of linking business with society for living together harmoniously. Globalization has set in with its major agenda to break down barriers. It brings a lot of good things to humanity, but also introduces challenges which humanity must face collectively and individually.

- Environment and justice issues related to natural resources and resources control;

- Employment and work related issues;

- Management and ownership and the corporate governance function;

- International business practices in African countries and corporate social responsibility and investments;

- Terrorism, security issues, cross border trading in arms and drugs;

- Business as a good servant promoting the common good and human dignity; and

- The management and use of means of modern communication, the media and the tools of the information and communication Technology.

\section{CONCLUSION}

We cannot do businesses without offering a level playing ground, respecting human dignity, respecting ownership and private property, promoting family values, encouraging and asserting the rights of individuals and communities, and without protecting them from exploitation, bad laws and big businesses that have grown bigger than nations and persons. Ultimately, what matters is happiness and that human beings are served by businesses. Business Ethics therefore emerges as an opportunity and platform for change and inclusion of human values in the way companies, corporations, governments, individuals and people manage their affairs, relate to the environment, control and manage resources and create an environment for peace, prosperity and development for all. The language of Business Ethics is one of inclusion, not exclusion.

Worldwide, humanity has experienced recent historical developments captured under the theme of globalization. Globalization has led in our times to communities, cultures and nations fast becoming united in ways and through means which had hitherto been thought to be impossible. The coming together of the various groups takes place not only through economic mergers, political integration, 
trade agreements and the like, but also through the use of recent technological discoveries. Globalization has its advantage, but its pitfalls are also apparent. In the African setting, many have pondered on the overall effect of this phenomenon on the peoples and cultures of the continent. Business Ethics is about sustainability. Short term sacrifices lead to long term gain. Sacrifices are only made, voluntarily for goals and ideals we believe in, and when we have confidence in those who may lead us there. Leadership therefore, become ever more important in this agenda for changing Africa's negative image, whether through the media or by those other levels involved in managing human affairs, the centers of social, academic, cultural and political change in the West and elsewhere.

In conclusion we recommend:

- That those who are engaged as teachers, trainers and students, and who work in the field of Business Ethics as practitioners enhance their collaboration and increase their activities in the West Africa sub-region and globally;

- That universities in the West Africa sub-region increase their curriculum and content of teaching, research and training to ensure that future students are instructed fully in the wisdom of Business Ethic for a better society; and

- That inter-university journals, symposia and workshops be organized to increase awareness of the urgent necessity of the field of Business Ethics amongst all levels of society, including the big global business players; communities; governments; individuals, civil society groups and faith based organizations.

\section{REFERENCES}

Achebe, C. 1958. Things fall apart. London: Heinemann.

Elegido, M. J. 1996. Fundamentals of Business Ethics. Ibadan: Spectrum. Edozien, N.N. 2007. Ownership and management structures in the economy. Enugu: CIDJAP.

Ike, O.F. 2004. Globalization and African self-determination - What is our future? Frankfut/M: IKO Verlag...,

Ike, O.F. 2003. Development is about people, business is about ethics. Enugu: CIDJAP.

Ike, O. F. 2001. Understanding Africa, traditional legal reasoning, jurisprudence and justice in Igboland as a basis for culturally rooted sustainable development. Enugu: SNAAP.

How to cite this article: Ike $O$. Business Ethics as a field of teaching, training and research in West Africa. Afr J Bus Ethics 2011;5:89-95.

Source of Support: Nil, Conflict of Interest: None declared

\section{AUTHOR}

Reverend Professor Monsignor Dr. Obiora Ike is Director of the Catholic Institute for Development Justice and Peace (CIDJAP) in Enugu and Professor of Ethics and African Studies at the Godfrey Okoye University. He studied Philosophy, Theology, Economic Ethics, Political Science and History across 5 countries (Nigeria, Austria, Germany, UK and France) from 1975 to 1986 and obtained five Degrees with a Doctorate and specialization in Catholic Ethics from the University of Bonn, Germany.

\section{Author Help: Online submission of the manuscripts}

Articles can be submitted online from http://www.journalonweb.com. For online submission, the articles should be prepared in two files (first page file and article file). Images should be submitted separately.

1) First Page File:

Prepare the title page, covering letter, acknowledgement etc. using a word processor program. All information related to your identity should be included here. Use text/rtt/doc/pdf files. Do not zip the files.

2) Article File:

The main text of the article, beginning with the Abstract to References (including tables) should be in this file. Do not include any information (such as acknowledgement, your names in page headers etc.) in this file. Use text/rtt/doc/pdf files. Do not zip the files. Limit the file size to $1024 \mathrm{~kb}$. Do not incorporate images in the file. If file size is large, graphs can be submitted separately as images, without their being incorporated in the article file. This will reduce the size of the file.

3) Images:

Submit good quality color images. Each image should be less than $\mathbf{4 0 9 6}$ kb (4 MB) in size. The size of the image can be reduced by decreasing the actual height and width of the images (keep up to about 6 inches and up to about $1800 \times 1200$ pixels). JPEG is the most suitable file format. The image quality should be good enough to judge the scientific value of the image. For the purpose of printing, always retain a good quality, high resolution image. This high resolution image should be sent to the editorial office at the time of sending a revised article.

4) Legends:

Legends for the figures/images should be included at the end of the article file. 
Reproduced with permission of the copyright owner. Further reproduction prohibited without permission. 